\title{
Heating Sector Decarbonization With Renewable Gas and Power-to-Heat
}

\author{
Robert Weiss \\ VTT Technical Research Centre of \\ Finland \\ Espoo, Finland \\ robert.weiss@vtt.fi
}

\author{
Heidi Saastamoinen \\ VTT Technical Research Centre of \\ Finland \\ Tampere, Finland \\ heidi.saastamoinen@vtt.fi
}

\author{
Jussi Ikäheimo \\ VTT Technical Research Centre of \\ Finland \\ Espoo, Finland \\ https://orcid.org/0000-0002-3920-0283
}

\begin{abstract}
Deep decarbonization, which comprehends activities whose aim is to reduce carbon dioxide emissions in all economic sectors, is necessary to reach the goals of the Paris agreement. Consumption of fossil fuels in individual buildings is an important source of emissions. In this paper we study the economic feasibility of decarbonizing heat generation in natural gas heated buildings in two European countries. Heat pumps and substitution of fossil natural gas by synthetic natural gas (SNG) are studied as solutions for decarbonization in both Finnish and German conditions. We find that in both countries the SNG solution substantially increases the consumer's heating costs. Heat pump turned out to be economically viable in Finland while in Germany the high surcharges on green electricity made the heat pump solution unattractive.
\end{abstract}

Keywords decarbonization, grid tariff, heat pump, green gas, SNG, power-to-heat, heating

\section{INTRODUCTION}

In the EU, the transition into a low carbon society will cover all the societal sectors, including the heating and cooling of buildings. Long term targets in the heating sector aim for more renewable integration, with studies indicating a shift to (renewable) gas, heat pumps (HP), and district heating (DH)[1]. To enable a broader decarbonization and a $100 \%$ renewable energy system, heat storages and sector coupling measures such as combined heat-and-power (CHP), power-toheat $(\mathrm{P} 2 \mathrm{H})$, and power-to-gas $(\mathrm{P} 2 \mathrm{G})$ are needed.

Natural gas plays an essential role in covering the space heating demand in EU-28: $43 \%$ of the space heating demand was covered by natural gas in 2017 [2]. In the EU-28, the space heating accounted for $64 \%(7,636 \mathrm{PJ})$ of the final energy consumption in residential sector in 2017 [3]. Therefore, natural gas heating is substantial source of greenhouse gas emissions. Gas space heating is especially dominant in Germany, Netherlands and the United Kingdom. In $2014,49.8 \%$ of new homes installed natural gas boiler in Germany, where as heat pump was installed in one in five homes $(21.5 \%)$ [4].

HP heating systems allow the use of renewable electricity in space heating. HP systems are popular and widely used for preparing domestic hot water and space heating in all over the Europe but especially in Nordic countries [5]. Total number of heat pumps in Europe increased 11\% from 2016 to 2017 [6]. However, e.g. in Finland, heat pump sales have substantially increased (30\% yearly increase in 2019) due to excellent profitability and new service models and in 2019 the total production corresponded to $15 \%$ of residential and service building stock heating [7]. The increase has been especially high in domestic ground source heat pumps [8]. In 2017 , total number of heat pumps in Germany was 974,750 and in Finland 794,602 [9], i.e. approximately the same, although Germany's population was 15 times to Finland's population.

Heating costs are a significant expenditure for many facility owners and residents, and there is not much room for cost increases. In addition, added value of replacing oil and gas boilers and renovating existing buildings if not often seen [6]. Well-designed and coordinated tariff policies for power and gas grids could stimulate the shift towards energyefficient heating based on $100 \%$ renewable energy. For most existing buildings, the gas boiler fed heating system could be combined with heat pumps. Heat pumps can deliver majority of needed heat energy and absorb excess grid or renewable power, while gas can serve peak heat consumption, reducing power grid constraints.

In this study, we show the impact of some tariff policies for gas and power grids on the heating customer's economy. For some residential building examples, we evaluate the building owner's willingness to invest in sector-coupling technologies such as building-integrated HP. We compare situation for a Nordic country and Germany, using their climate, building standards, and tariff policy differences.

Results show the economic decarbonization potential of the sector-coupling building heating solutions. We point out, how tariff policies could boost investment and high utilization of HP, and decrease GHG emissions. In addition, we show that expensive renewable gas does not lead to substantially higher heating costs. 


\section{MATERIAL AND METHODS}

\section{A. Gas and power tariff policies for residential heating}

The gas tariffs in our scenario calculations are listed in Table I below. In Germany and Finland, end customer tariffs are available for fossil natural gas (NG) and green biogas (BG). For Germany, the used gas tariffs are based on multifamily apartment price estimates, published for NG in [10]. BG tariff components are based on 100 euro/MWh offers from retailers[11] and the retail costs and network fees from the NG tariff structure. For Finland we used similar offers for NG and BG from local retailers to heating end customers.

Synthetic natural gas (SNG) produced in power-to-gas facilities is not yet available on the heating market, but we estimate the structure of possible SNG tariffs using the same retailer's markup and network fees. We estimated SNG end customer tariffs for an optimistic 100 euro/MWh production cost scenario [12] and a pessimistic 200 euro/MWh production cost scenario[13] [14].

TABLE I. GAS TARIFF SCENARIOS
Concerning power tariff policy, there are large differences between Finland and Germany. In Finland, for building owners with electrical or heat pump heating, approximately $40 \%$ of the electrcity price of $120-140$ euro/MWh goes to the retailer. The rest consists of network fees and taxes, which is the focus in this work. Therefore, to make comparisons more easily, we used a green power contract with fixed price 52.50 euro/MWh for the energy component in both countries, based on publicly available offers from power providers[15].

In Germany, power is considerably more expensive (280 euro/MWh in 2019) for residential end customers. However, for heat pump customers, there are special heat pump tariffs called "Wärmepumpenstrom" which are clearly cheaper, average 213 euro/MWh[16], and green power offers of 204 euro/MWh were found by the authors. These tariffs have often the requirement that the heat pump must have separate power grid connection, allowing load control by the power provider or DSO during few predefined peak hours each day[17].

Germany has had since year 2000 a progressive feed-in tariff policy for solar and wind power, creating the first real markets for these technologies and provide pioneers and first move industrial players an stimulating development,

\begin{tabular}{|c|c|c|c|c|c|c|c|c|}
\hline \multirow{2}{*}{ Gas Tariff euro/MWh } & \multicolumn{4}{|c|}{ Finland } & \multicolumn{4}{|c|}{ Germany } \\
\hline & NG80 & BG90 & SNG147 & SNG272 & NG56 & BG100 & SNG145 & SNG264 \\
\hline Fossil or Green gas & Fossil & $\begin{array}{l}\text { Green } \\
\text { Biogas }\end{array}$ & $\begin{array}{l}\text { Green } \\
\mathrm{SNG}^{\mathrm{b}}\end{array}$ & $\begin{array}{l}\text { Green } \\
\mathrm{SNG}^{\mathrm{c}}\end{array}$ & Fossil & $\begin{array}{l}\text { Green } \\
\text { Biogas }\end{array}$ & $\begin{array}{l}\text { Green } \\
\mathrm{SNG}^{\mathrm{b}}\end{array}$ & $\begin{array}{l}\text { Green } \\
\mathrm{SNG}^{\mathrm{c}}\end{array}$ \\
\hline $\begin{array}{l}\text { Natural gas wholesales price or } \\
\text { biogas/SNG production price }\end{array}$ & $24,92 €$ & $53,26 €$ & $100,00 €^{\mathrm{b}}$ & $200,00 €^{\mathrm{c}}$ & $24,92 €$ & $68,50 €$ & $100,00 €^{\mathrm{b}}$ & $200,00 €^{\mathrm{c}}$ \\
\hline Retail costs and markup & $3,00 €$ & $3,00 €$ & $3,00 €$ & $3,00 €$ & $3,00 €$ & $3,00 €$ & $3,00 €$ & $3,00 €$ \\
\hline Network fees & $16,21 €$ & $16,21 €$ & $16,21 €$ & $16,21 €$ & $12,60 €$ & $12,60 €$ & $12,60 €$ & $12,60 €$ \\
\hline VAT $19 \%$ (on prev..items) & & & & & $7,57 €$ & $0,00 €$ & $7,57 €$ & $7,57 €$ \\
\hline Energy taxes \& levies & $21,82 €$ & $0,00 €$ & $0,00 €$ & $0,00 €$ & $7,70 €$ & $15,98 €$ & $21,96 €$ & $40,96 €$ \\
\hline VAT $24 \%$ (on all items) & $15,83 €$ & $17,39 €$ & $28,61 €$ & $52,61 €$ & & & & \\
\hline Heating end customer tariff & $81,78 €^{\mathrm{a}}$ & $89,86 €^{\mathrm{a}}$ & $147,82 €^{\mathrm{b}}$ & $271,82 €^{\mathrm{c}}$ & $55,79 €^{\mathrm{a}}$ & $100,08 €^{\mathrm{a}}$ & $145,14 €^{\mathrm{b}}$ & $264,14 €^{\mathrm{c}}$ \\
\hline
\end{tabular}

a. According to offers from the market

b. Estimated future tariff, using lower range 100euro/MWh for the production price

c. Estimated future tariff, using higher range 200euro/MWh for the production price

The used power tariff in our scenario calculations are listed in Table II below.

TABLE II. POWER TARIFF IN THE SCENARIOS

\begin{tabular}{|l|c|c|}
\hline \multirow{2}{*}{\multicolumn{1}{|c|}{ Heat Pump Customers }} & \multicolumn{2}{|c|}{ Scenario 2019 } \\
\cline { 2 - 3 } Power Tariff euro/MWh & Finland & Germany \\
\hline Fossil or Green Power & Green & \multicolumn{1}{c|}{ Green } \\
Power Retail Energy & $52,50 €$ & $52,50^{\mathrm{c}} €$ \\
Network fees & $25,32 €$ & $30,00^{\mathrm{c}} €$ \\
EEG-surcharge & & $68,80 €$ \\
and KWK-fee (Germany) & & $20,50 €$ \\
Other energy taxes \& levies & $22,58 €$ & \\
VAT 24\% (Finland) & $24,10 €$ & \\
VAT 19\% (Germany) & & $32,64 €$ \\
\hline Heating end customer tariff & $124,50 €$ & $204,44 €$ \\
\hline
\end{tabular}

Estimated cost breakdown of the offered heat pump tariff investment and operation environment. This policy has been funded by the power end customers via a surcharge on top of the network tariff, the so called EEG-surcharge. The EEGsurcharge was below 10 euro/MWh until 2007, but increased to over 60 euro/MWh with the rapid renewable power expansion following the Energiewende after 2013. Today, most new solar and wind project do receive minimal or no feed-in tariffs at all, but the EEG-surcharge has still to fund the pioneering but expensive old installations.

Finland has had a limited feed-in tariff policy, only for a limited amount of wind power installations and no feed-in tariff at all for solar power. The feed-in tariffs are funded from the national budget, so there is no funding required from power tariffs and hence no surcharges to fund feed-in tariffs. Other taxes, levies and the network fees are in total also lower than in Germany, except for the higher 24\% VAT. In our calculations, we used the network fees of the DSO [18] responsible for the city of Espoo in Finland. 


\section{B. Studied building examples}

Two residential buildings located in the city of Espoo, Southern Finland (marked FI in Table III) have been studied in detail and modeled using hourly energy meter readings from smart meters and heating control systems as well as energy audits. In this study, the models made for the Finnish buildings are exploited in generating comparable location specific energy consumption behavior curves and patterns for the buildings in Southern Germany, where the city of Nürnberg was selected as location for the comparison (marked as GER).

TABLE III. STUDIED EXAMPLE BUILDINGS

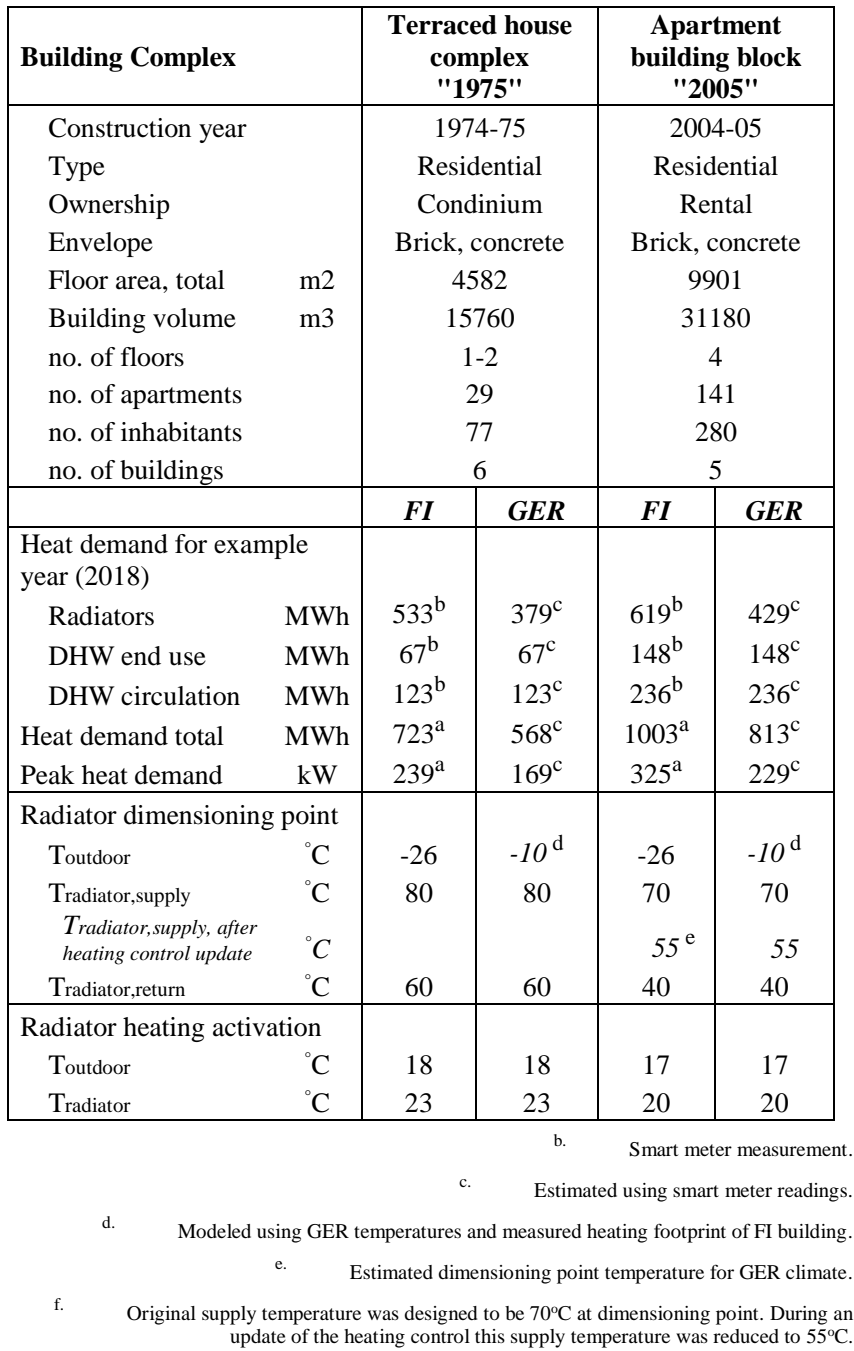

The main focus in this study is a Finnish rental apartment building complex, marked with "2005" in Table III, consisting of 5 buildings with 4 floors each, altogether a floor area of $9901 \mathrm{~m}^{2}$ in 141 apartments of size 1-4 rooms+ kitchen+bathroom. This building complex was constructed in 2004-05 according to Finnish building code valid at that time. The building complex has a hydronic central heating system consisting predominantly of radiators. The radiator heating system energy supply is mainly controlled with the supply temperature using the outdoor temperature as input signal for the control curve (see Fig 1). During an update of the heating control system, this supply temperature has been reduced substantially, from $70{ }^{\circ} \mathrm{C}$ to $55^{\circ} \mathrm{C}$ at the dimensioning point ($26^{\circ} \mathrm{C}$ in Southern Finland). Domestic hot water (DHW) is supplied from the same central heating system to the apartments at a supply temperature of $\mathrm{T}_{\mathrm{DHW}}$,supply $=58{ }^{\circ} \mathrm{C}$, and a DHW circulation line ensures that the DHW temperature in the apartments immediately above $55^{\circ} \mathrm{C}$ when turning on the hot water tap. The same DHW circulation line is used for radiator heating in the bathrooms, ensuring bathroom heating comfort also when the ordinary radiator system is not activated (typically at outdoor temperature above $17{ }^{\circ} \mathrm{C}$ ). At the same time, these DHW end use and DHW circulation loads provide a heat load that is present also outside the normal heating season.

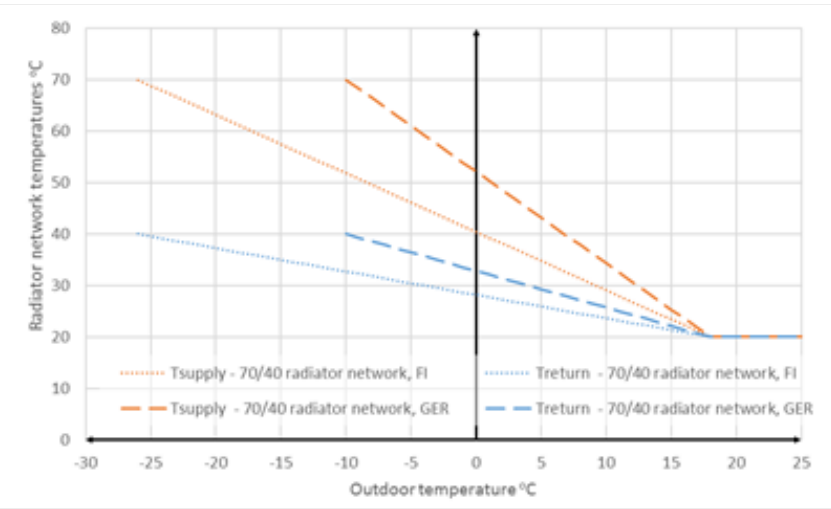

Fig 1 Radiator network control curves (Tradiator,supply, Tradiator,return) approximated for South Finland (FI) and estimated for Southern Germany (GER) for a common 70/40 radiator heating system.

The second building complex in this study, marked with "1975", is a Finnish terraced house complex consisting of 6 buildings with 1-2 floors each, altogether a floor area of 4582 $\mathrm{m}^{2}$ in 29 larger family apartments of size 4-6 rooms+kitchen+1-2bathrooms+sauna. This building complex was constructed in 1974-75 according to Finnish building code valid at that time. The building complex has also a hydronic central heating system consisting of radiators, but with considerably higher supply temperature of $80{ }^{\circ} \mathrm{C}$ at dimensioning point, which is typical for that era. There is also a DHW supply system with DHW circulation, which has approximately same temperature levels as the one in the "2005" building.

Both buildings have their central heating systems supplied with district heating $(\mathrm{DH})$ via a $\mathrm{DH}$ substation. At the $\mathrm{DH}$ substation, the DH supplier has a smart meter collecting hourly meter readings of the momentary DH energy consumption. Consequently, detailed outdoor temperature dependencies and hour-to-hour patterns of the building heating and DHW consumption behaviour could be modeled as background for this study. These metered consumption dependencies and patterns are in this study used to estimate the heat need for central heated buildings of same construction type, although they were using gas instead of DH. To generalize, it is assumed that the building complex has its own central gas boiler instead of one at the DH substation. 


\section{Air-to-water heat pump solution and costs}

In this study, the focus is on the feasibility of hybrid heat pump / auxiliary heater solutions. The focus of the analysis is

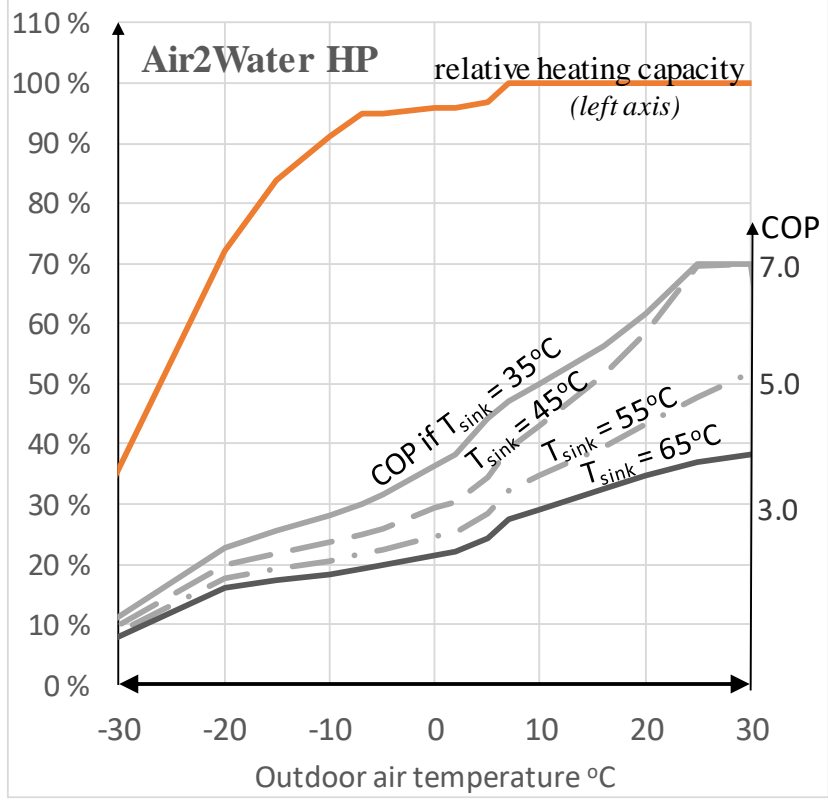

Fig 2 Modeled Air-to-water heat pump characteristics

on the large building-level air-to-water heat pumps (A2W $\mathrm{HP}$ ), typically installed for $10-500 \mathrm{~kW}$ heating capacity and used to supply heat to centralized hydronic heating systems. air-to-water heat pumps typically do not suffer from installation restrictions, unlike ground-source heat pumps.

The coefficient of performance COP, i.e. the ratio of useful heat output to power input, of the air-to-water heat pump is modelled using equation

$$
\text { COP }=\eta\left(T_{\text {air }}\right) \cdot \frac{\left(T_{\text {sink }}+273.15^{\circ} \mathrm{C}\right)}{T_{\text {sink }}-T_{\text {source }}}
$$

where $T_{\text {sink }}$ and $T_{\text {source }}$ are the temperatures (in ${ }^{\circ} \mathrm{C}$ ) of the heat exchanger on the hot (sink) side and cold (source) side, respectively. $\eta\left(T_{\text {air }}\right)$ is a dimensionless degradation factor, describing process imperfections compared to ideal Carnot cycle. For the modeled A2W HP, $T_{\text {source }}$ is set in this study to be equal to the air temperature $T_{\text {air }}$. For this model, $\eta\left(T_{\text {air }}\right)$ was then calibrated towards COP data from heat pump manufactures for large $15-80 \mathrm{~kW}$ heat pump units[19][20], and reached for this data at best 0.47 at an outdoor temperature range between $7{ }^{\circ} \mathrm{C}$ and $16{ }^{\circ} \mathrm{C}$, while being clearly less at lower or higher outdoor temperatures. Similarly, maximum heating capacity was calibrated in the same way to the manufacturer data. The resulting dependencies of COP and maximum heating capacity on outdoor air temperature are displayed in Fig 2.

For the delivered heat from the A2W HP to the radiator or DHW system, the delivered temperature is set to be $3{ }^{\circ} \mathrm{C}$ lower than $\mathrm{T}_{\text {sink. }}$. If this delivered temperature is less than required by radiator or DHW supply temperature, an auxiliary electric heater or gas heater/boiler must supply the remaining temperature lift and heat energy.
Interest free investment costs for the A2W HP are estimated based experience from on projects in Finland, and displayed in table IV.

TABLE IV. HEAT PUMP SPECIFIC INVESTMENT COSTS

\begin{tabular}{|l|r|}
\hline $\begin{array}{c}\text { A2W Heat Pump Investment } \\
\text { estimated costs, large HP }\end{array}$ & $\begin{array}{c}\text { euro per } \\
\text { kW,heat }\end{array}$ \\
\hline HP Unit & $300,00 €$ \\
Storage Unit & $71,00 €$ \\
Outdoor Unit & $180,00 €$ \\
\hline Equipment Cost Total & $551,00 €$ \\
Installation markup 50\% & $275,50 €$ \\
\hline Total Project Cost & $826,50 €$ \\
\hline
\end{tabular}

\section{Optimization model}

For the analysis calculations we use a linear optimization model "SmartP2DH" developed at VTT and dedicated for building level power-to-heat and sector coupling energy analysis. The model is illustrated in Fig. 3 below, and handles building-level heat pump investments and operation in a future smart energy network.

The optimization model includes configurable building heating system characteristics. These include e.g. forecast for the building heating needs depending on the outdoor air temperature adjusted with average heat gains from residents and devices, the ability to handle radiator network supply and return temperature curves which depend on outdoor air temperature (see e.g. Fig. 1), DHW weekly consumption patterns and DHW circulation needs and temperature levels, as well as resident's weekly power consumption patterns.

The model is designed to handle and optimize both operations and energy production investments for a building connected to several grids, i.e. power, gas and/or district heating grid, and the contracts to the energy retailers and grids.

For the power-to-heat and sector coupling analysis, the model has models for gas boiler and district heating operation, as well as submodels for several heat pump technologies including A2W HP, that depend on various heat sources with dynamic temperature behaviour. The model calculates with the optimization both the cost-optimal dimensions of grid connections as well as for each hour the cost-optimal temperature lift, i.e. cost optimal preheating operation, of the given heat pump configuration. The model also calculates the $\mathrm{CO} 2$-emissions, including both direct emissions as well as grid emissions. 


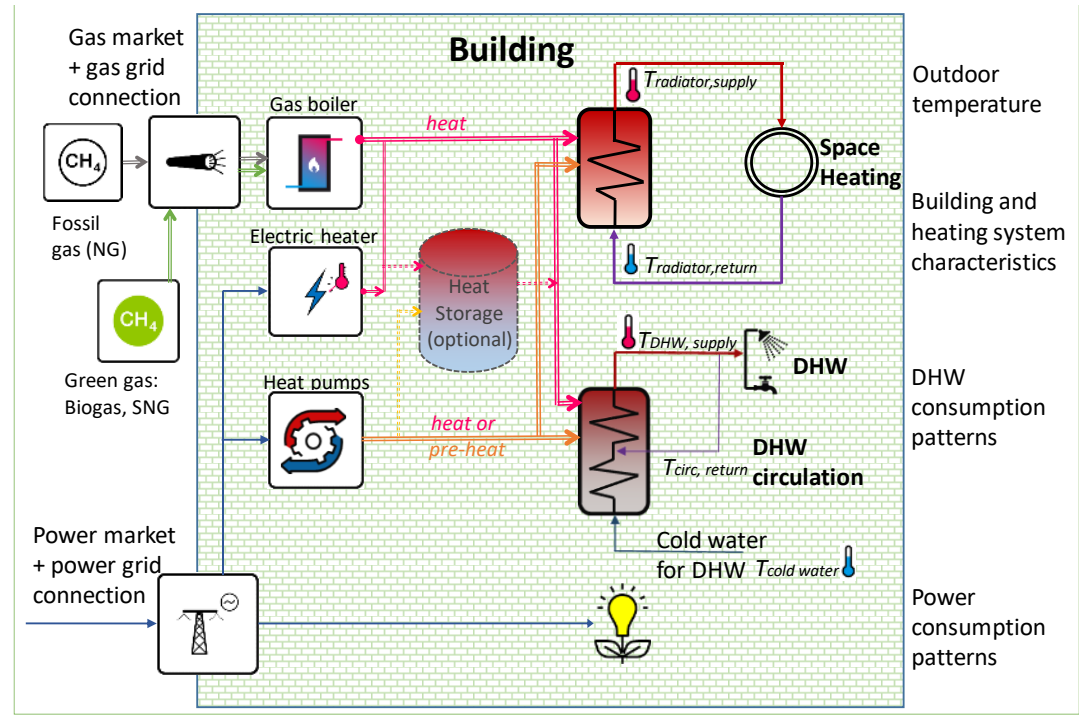

Fig 3 Schematic of the Optimization model

\section{E. Scenario definitions}

The studied scenarios include combinations of gas tariff scenarios (section II) and different heating systems. The heating system may consist of gas boiler alone (baseline/noHP) or boiler and a cost optimal A2W heat pump (A2WHP). In the latter case, the optimization model results provide the cost optimal A2WHP size for the scenario, typically to a certain part load level of the peak heat demand.These scenarios are calculated for both Finnish (FI) weather and green power tariffs, as well as German (GER) weather and green power tariffs available for heat pump customers. Table V shows the full description of all scenarios.

TABLE V. DEFINED SCENARIOS
For the example years studied, we used weather data with hourly time series for the outdoor temperature for one example year. For Finland, we use measurements for the year 2018 from Finnish Meteorological weather station in Tapiola, Espoo, with temperature average $6.8^{\circ} \mathrm{C}$, high $30.2^{\circ} \mathrm{C}$ and low $20.8^{\circ} \mathrm{C}[21]$. For Germany, we used the MERRA-2 time series provided by renewables.ninja tool for Langwasser, Nürnberg, with average $10.0^{\circ} \mathrm{C}$, high $33.7^{\circ} \mathrm{C}$ and low $-8.9^{\circ} \mathrm{C}$ [22].

In all scenarios, the interest rate applied by the consumer for financing the investments was assumed to be $3 \%$. The relatively low discount rate was motivated by the fact that residential building owners can often get long term loans for very low interest rates, today even below $1.5 \%$, as long as the property market is considered at least as stable. Lifetime of air-to-water heat pumps was assumed to be 20 years.

\begin{tabular}{|c|c|c|c|c|c|c|c|c|c|}
\hline Scenario definition - Finland & $\begin{array}{c}\text { NG80 } \\
\text { Baseline }\end{array}$ & $\begin{array}{c}\text { NG80 } \\
\text { A2WHP }\end{array}$ & $\begin{array}{l}\text { BG90 } \\
\text { noHP }\end{array}$ & $\begin{array}{c}\text { SNG147 } \\
\text { noHP }\end{array}$ & $\begin{array}{c}\text { SNG272 } \\
\text { noHP }\end{array}$ & $\begin{array}{c}\text { Max } \\
\text { A2WHP } \\
\end{array}$ & $\begin{array}{c}\text { BG90 } \\
\text { A2WHP }\end{array}$ & $\begin{array}{l}\text { SNG147 } \\
\text { A2WHP } \\
\end{array}$ & $\begin{array}{l}\text { SNG272 } \\
\text { A2WHP }\end{array}$ \\
\hline Fossil or green gas & Fossil & Fossil & $\begin{array}{l}\text { Green } \\
\text { Biogas }\end{array}$ & $\begin{array}{l}\text { Green } \\
\text { SNG }\end{array}$ & $\begin{array}{l}\text { Green } \\
\text { SNG }\end{array}$ & & $\begin{array}{l}\text { Green } \\
\text { Biogas }\end{array}$ & $\begin{array}{l}\text { Green } \\
\text { SNG }\end{array}$ & $\begin{array}{l}\text { Green } \\
\text { SNG }\end{array}$ \\
\hline $\begin{array}{l}\text { Gas boiler } \\
\text { peak heat demand size }\end{array}$ & $\mathrm{X}$ & $\mathrm{X}$ & $\mathrm{X}$ & $\mathrm{X}$ & $\mathrm{X}$ & & $\mathrm{X}$ & $\mathrm{X}$ & $\mathrm{X}$ \\
\hline $\begin{array}{l}\text { A2W Heat Pump } \\
\text { cost optimal or maximal size }\end{array}$ & & Optimal & & & & Max & Optimal & Optimal & Optimal \\
\hline $\begin{array}{l}\text { Electric heater } \\
\text { peak heat demand size }\end{array}$ & & & & & & $\mathrm{X}$ & & & \\
\hline Gas Tariff, eur/MWh & $82 €$ & $82 €$ & $90 €$ & $147 €$ & $272 €$ & & $90 €$ & $147 €$ & $272 €$ \\
\hline Green Power Tariff, eur/MWh & $125 €$ & $125 €$ & $125 €$ & $125 €$ & $125 €$ & $125 €$ & $125 €$ & $125 €$ & $125 €$ \\
\hline Scenario definition - Germany & $\begin{array}{c}\text { NG57 } \\
\text { Baseline }\end{array}$ & $\begin{array}{c}\text { NG57 } \\
\text { A2WHP }\end{array}$ & $\begin{array}{l}\text { BG100 } \\
\text { noHP }\end{array}$ & $\begin{array}{c}\text { SNG145 } \\
\text { noHP }\end{array}$ & $\begin{array}{c}\text { SNG264 } \\
\text { noHP }\end{array}$ & $\begin{array}{c}\text { Max } \\
\text { A2WHP }\end{array}$ & $\begin{array}{c}\text { BG100 } \\
\text { A2WHP }\end{array}$ & $\begin{array}{l}\text { SNG145 } \\
\text { A2WHP }\end{array}$ & $\begin{array}{l}\text { SNG264 } \\
\text { A2WHP }\end{array}$ \\
\hline Fossil or green gas & Fossil & Fossil & $\begin{array}{l}\text { Green } \\
\text { Biogas }\end{array}$ & $\begin{array}{l}\text { Green } \\
\text { SNG }\end{array}$ & $\begin{array}{l}\text { Green } \\
\text { SNG }\end{array}$ & & $\begin{array}{l}\text { Green } \\
\text { Biogas }\end{array}$ & $\begin{array}{l}\text { Green } \\
\text { SNG }\end{array}$ & $\begin{array}{l}\text { Green } \\
\text { SNG }\end{array}$ \\
\hline $\begin{array}{l}\text { Gas boiler } \\
\text { peak heat demand size }\end{array}$ & $\mathrm{X}$ & $\mathrm{X}$ & $\mathrm{X}$ & $\mathrm{X}$ & $\mathrm{X}$ & & $\mathrm{X}$ & $\mathrm{X}$ & $\mathrm{X}$ \\
\hline $\begin{array}{l}\text { A2W Heat Pump } \\
\text { cost optimal or maximal size }\end{array}$ & & Optimal & & & & Max & Optimal & Optimal & Optimal \\
\hline $\begin{array}{l}\text { Electric heater } \\
\text { peak heat demand size }\end{array}$ & & & & & & $\mathrm{X}$ & & & \\
\hline Gas Tariff, eur/MWh & $56 €$ & $56 €$ & $100 €$ & $145 €$ & $264 €$ & & $100 €$ & $145 €$ & $264 €$ \\
\hline Green Power Tariff, eur/MWh & $204 €$ & $204 €$ & $204 €$ & $204 €$ & $204 €$ & $204 €$ & $204 €$ & $204 €$ & $204 €$ \\
\hline
\end{tabular}




\section{RESULTS}

In this section, we shortly present results for the defined scenarios for gas heating and hybrid heat pump operation, for the example buildings in both Finland and Germany. Our focus is on the example building " 2005 " with $70 / 40$ heating system, since it can be considered to represent an average case. Results from other two example heating systems give an indication on the sensitivity of the results. Here the "2005" building with 55/40 radiator heating system can be considered to represent the situation of an energy efficient (but not near zero energy) building after a well performed heating system upgrade, while the " 1975 " building with $80 / 60$ system the typical situation of the old building stock built 30-60 years ago, but not renovated.

\section{A. Hybrid operation combining heat pump and gas boiler}

The optimization results showed clearly the advantage of a hybrid heat pump heating solution. The heat pump generally operated as base load unit throughout the year, while the gas boiler served generally as peak unit during winter time, as displayed in Fig. 4.

In summertime, the A2W heat pump generally supplied all needed DHW and space heat, reaching on average a COP of 4 in Germany, and reached almost same levels in Finland.

During coldest days in wintertime, the $\mathrm{A} 2 \mathrm{~W}$ heat pump efficiency decreased because of low outdoor temperature, and operation of the gas boiler became more cost-efficient. To increase the heat pump efficiency and COP, the heat pump performed only pre-heating to $45-52^{\circ} \mathrm{C}$ during the cold days, while the gas boiler performed the remaining lift to the required supply temperatures of the radiator system $\left(\mathrm{T}_{\text {radiator,supply }}\right)$ and DHW system ( $\left.\mathrm{T}_{\mathrm{DHW} \text {,supply }}\right)$, as displayed in Fig. 5. Still, there was only a small decrease in the heating capacity of the A2W heat pump during the coldest day in South Germany, as can be seen in Fig.5. In Finland, the heating capacity of $\mathrm{A} 2 \mathrm{~W}$ heat pump decreased substantially more because of outdoor temperatures falling below $-20^{\circ} \mathrm{C}$.
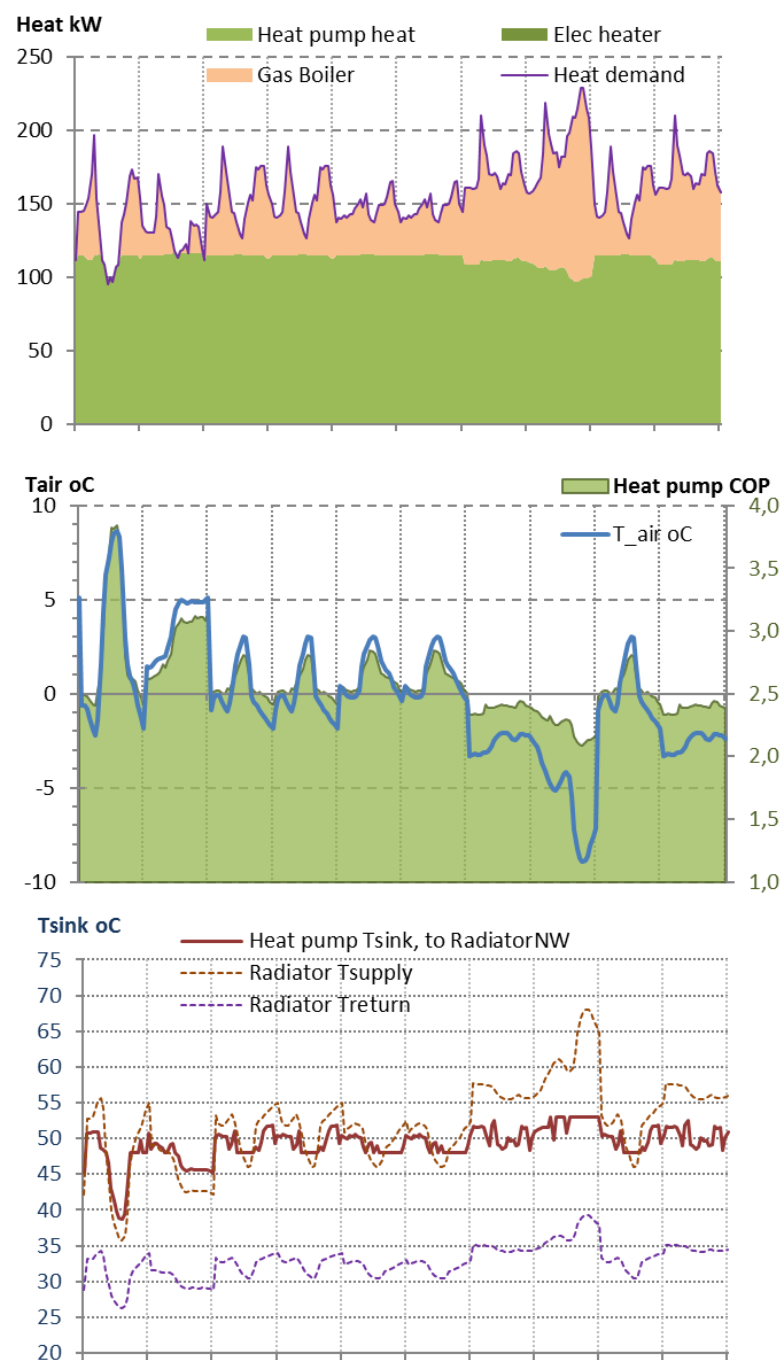

Fig 4 Hourly heat production during last 10 days of the example year Building "2005" with 70/40 radiator system in Germany, 120kW A2WHP with biogas boiler (Scenario BG100+A2WHP-GER).

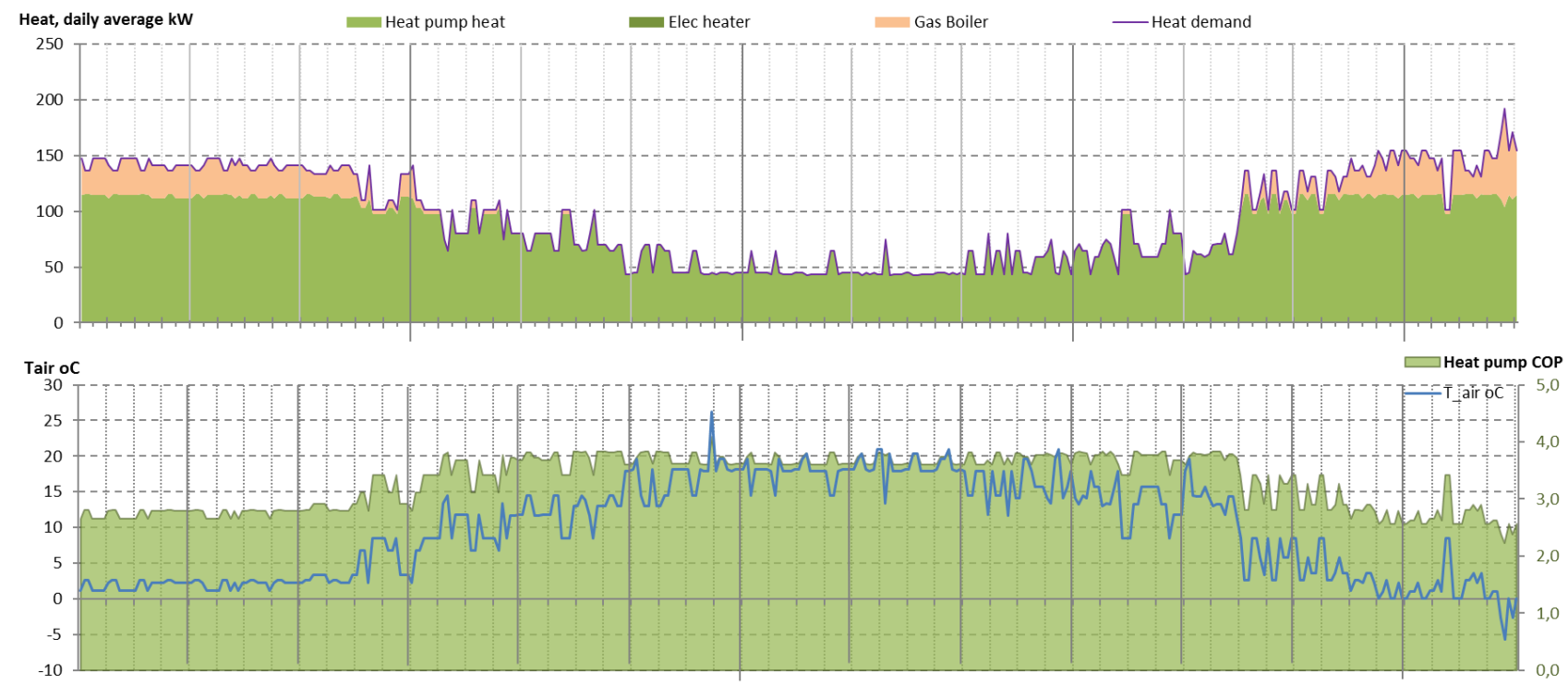

Fig 5 Daily average heat production during the example year, combining biogas and an A2WHP dimensioned to $52 \%$ of the peak heat load. Building " 2005 " with 70/40 radiator system in Germany, $120 \mathrm{~kW}$ A2W heat pump (Scenario BG100+A2WHP-GER). 


\section{B. Yearly heating energies, COP, costs and emissions}

For the scenarios, results for yearly heating energies provide by the heat pump and boiler, as well as related costs and $\mathrm{CO}_{2}$ emissions are displayed in Table VI below.

We can note that with the optimal combination of A2W heat pump and gas boiler, generally a seasonal COP of 3 can be reached. If the tariff policy is in favor for heat pump investments, i.e. the power costs are low enough compared to gas costs, the A2W heat pumps would be sized to $46-74 \%$ of the peak heat demand.

TABLE VI. RESULTS FOR BUILDING “2005” WITH 70/40 RADIATOR HEATING SYSTEM
Higher (green) gas price would lead to larger heat pump investment. Low fossil NG price, again, combined with high power prices would lead to very small or no heat pump investments at all, preventing sector coupling and cost efficient decentralized green heat production.

The scenarios that favor heat pumps investments show the gas consumption will decrease substantially in those scenarios. For most of the scenarios reducing, yearly gas consumption would be reduced below $12 \%$, and for the SNG scenarios even below 4\%, compared to the baseline. This low gas need could practically mean that scarce resources of BG and SNG could maybe be sufficient as peak gas, if a general hybrid heat pump scenario would be promoted by new favorable power and gas tariff policies.

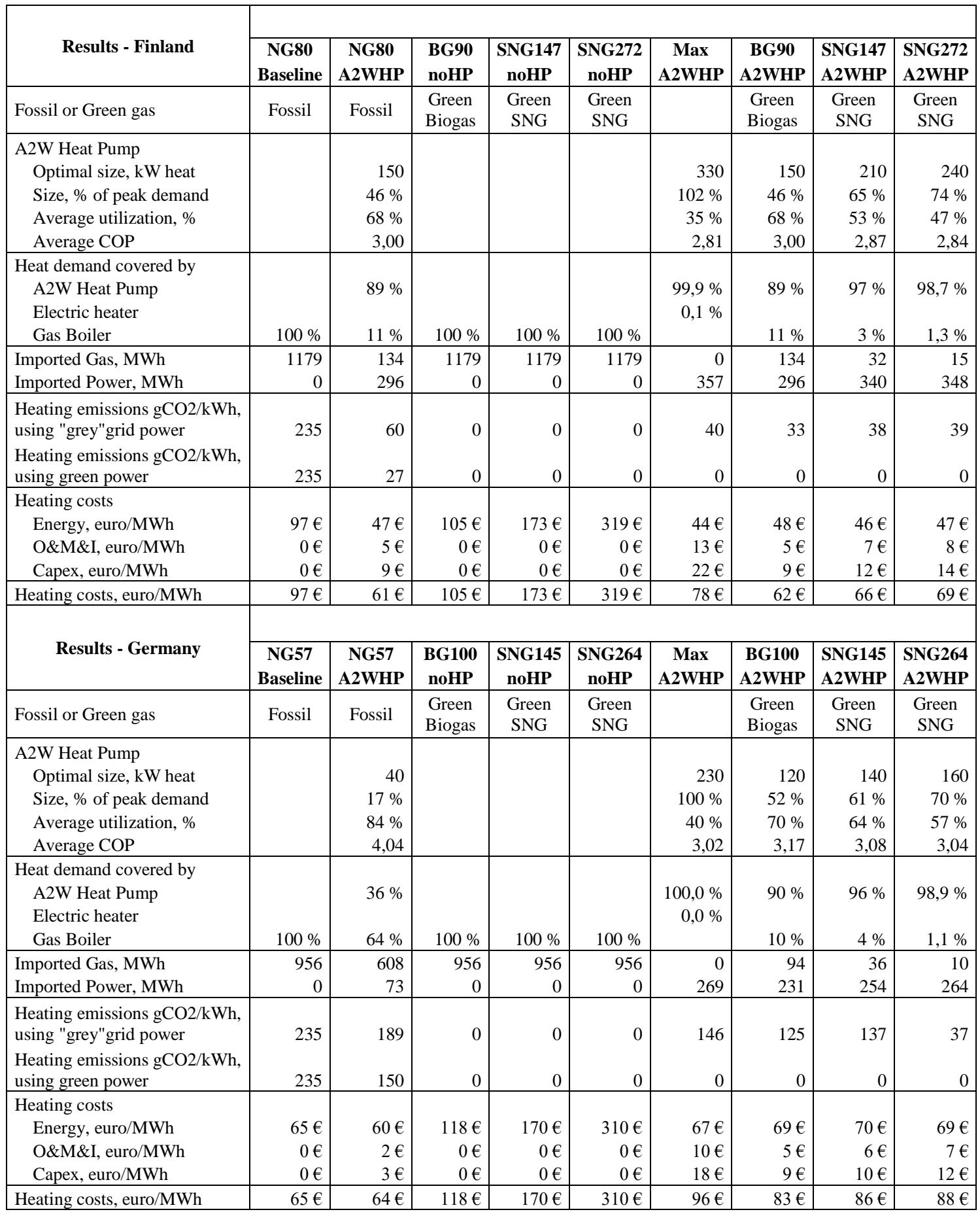




\section{Differences between building types, impact of radiator heating curve}

Figure 6 shows the impact of radiator control curve and the building type on relative heating cost, gas consumption and heat pump utilization in the hybrid gas boiler - heat pump solution. The comparison was made for the German case.

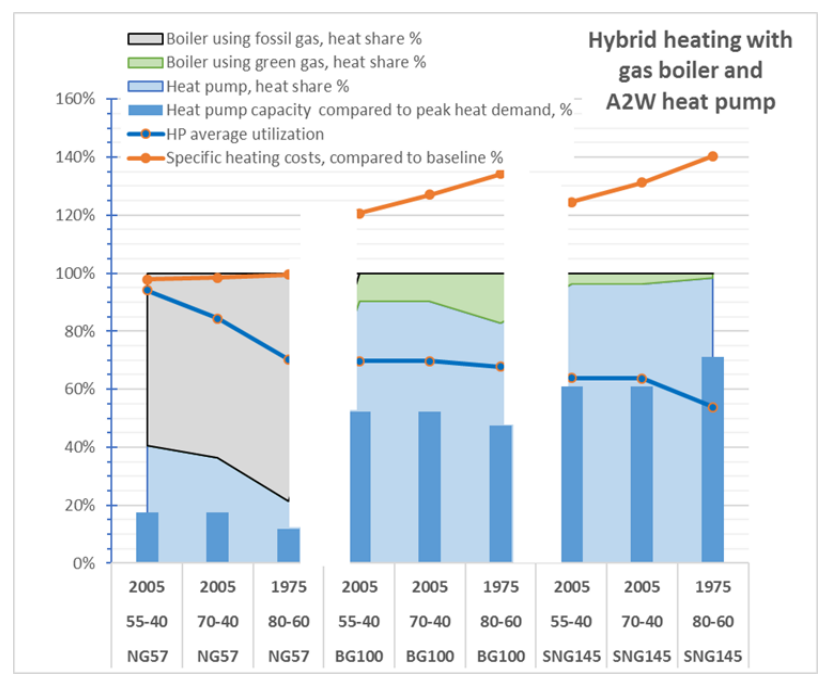

Fig 6 Heat production shares and relative heating costs for different gas price scenarios, building types. The results for radiator control curves with $55^{\circ} \mathrm{C}$ supply and $70{ }^{\circ} \mathrm{C}$ supply for the " 2005 " building are also shown.

We see that in the base gas price scenario (NG57) higher temperature radiators lead to higher gas consumption and lower heat pump utilization because of the reduced COP. When gas price increases, the effect disappears.

\section{Breakdown of the heating costs}

Figures 7 (Finland) and 8 (Germany) show the breakdown of heating costs in the different scenarios.

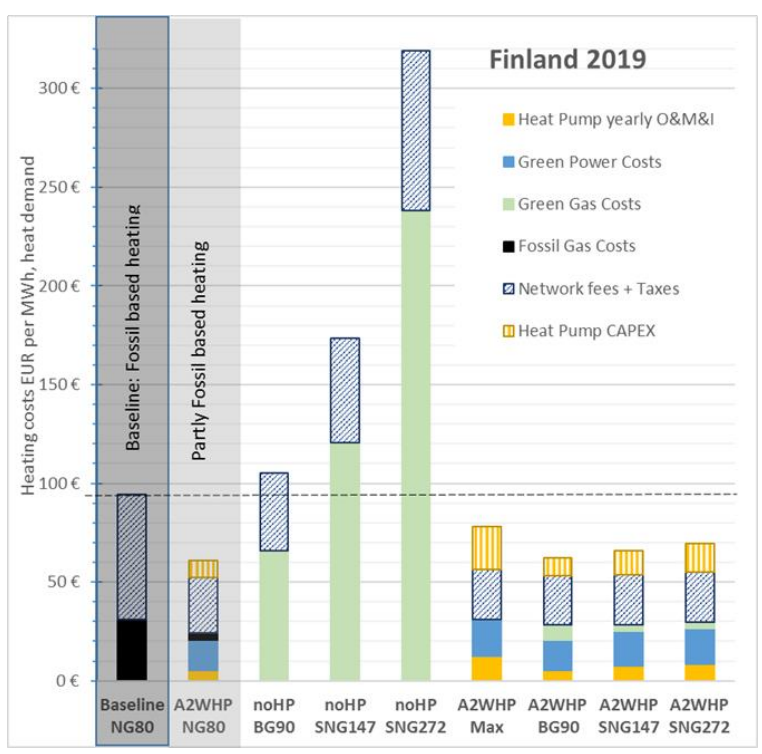

Fig 7 Shares of the heating costs for the appartment building "2005" with 70/40 radiator system, estimated for Finland in 2019.

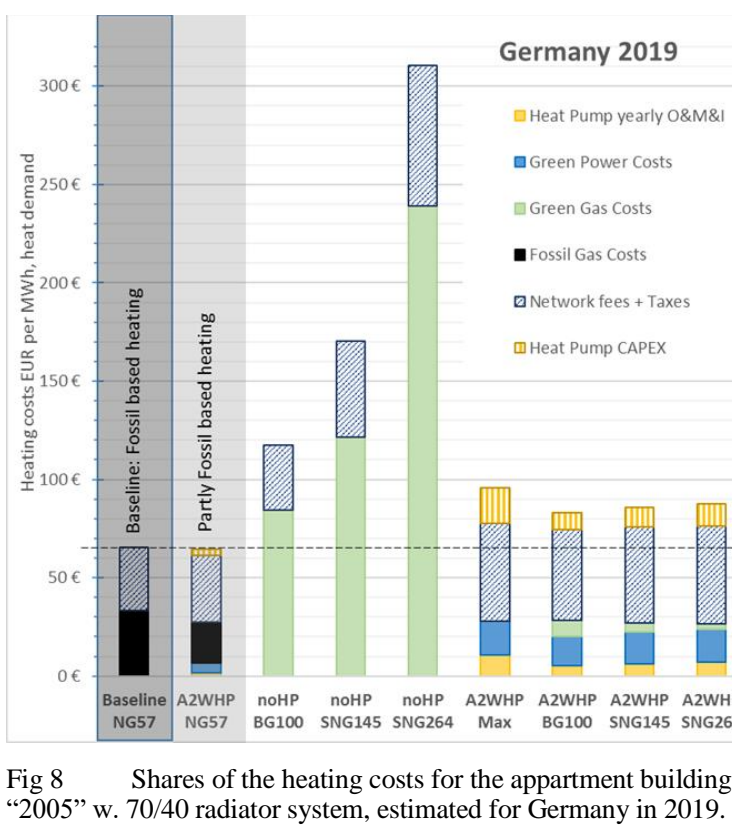

In Finland augmenting the gas boiler by A2WHP leads to clear reduction of heating costs and gas consumption. This is true even if gas is substituted by biogas or SNG. In Germany very little cost reduction is obtained although investment into a small heat pump is economically viable. If gas is substituted by biogas or SNG, some increase in heating cost is inevitable but it is held back by installation of a larger heat pump.

In both countries substitution of natural gas by biogas or SNG lead to large heating cost increases. 


\section{DISCUSSION}

In this section, we shortly discuss the decarbonization potential of the presented heating solutions, the favorable situation in Finland, and present briefly one way to help Germany to improve the heat pump investment climate to enable a cost efficient pathway for building heating decarbonization.

\section{A. Decarbonization potential of green gas alone}

The analysis showed clearly for both Finland and Germany, that all green gas scenarios i.a. those using biogas or SNG are still too expensive to provide a market based decarbonization of the residential building heating.

Still, green gas can provide an essential component as peak fuel in a decarbonised hybrid heating solution. However, in this case, the green gas consumption has a very small share of the total energy consumption, where as in original scenario fossil gas consumption covered the entire heating energy consumption.

\section{B. Decarbonization potential of heat pump solution}

For a heat pump to be a real decarbonization solution, green power or low carbon power must be used. Such green power contracts are available in both of the countries at no or only small premium compared to ordinary power contracts.

For Finland, power tariffs and calculation results showed that a heat pump heating solution has already a very significant decarbonization potential. A relatively high fuel tax is levied on natural gas in Finland, and with such tax structures a market based national approach is sufficient enough and no tariff policy changes are needed to enhance heat pump investments. This can be seen in ascending heat pump installation trends in Finland and Sweden.

For Germany, the situation is the opposite. With current German power and gas tariff policies, there is no real market based potential for the heating decarbonization using heat pumps. Fossil natural gas is still relatively cheap, while power is plagued from high grid tariffs, the high EEG-surcharge (whose purpose is to remunerate electricity from renewable energy sources) and other levies like the KWK-Ablage (whose purpose is to remunerate CHP producers), other energy taxes and on top of all these burdens, a 19\% value added tax (VAT). Consequently, heat pump investment is not profitable except in very small scale.

\section{Impact of CO2-tax on fossil heating fuels}

To look for alternative tariff solutions that could enhance the German situation, we investigated the impact of a $\mathrm{CO}_{2}$-tax of 50 euro/ton $\mathrm{CO}_{2}$ on fossil heating fuels, in addition to the existing taxes listed in Table 1. This tax would have an cost impact of 10 euro/MWh natural gas + VAT19\%, total 11.90 euro/MWh natural gas. This would result in Germany in a $21 \%$ increase on the resident's heating bill to $69 \mathrm{euro} / \mathrm{MWh}$ (still cheaper than in Finland), if no other measures can be taken to reduce the heating bill. However, the gas price increase would not trigger heat pump investments, since the heat pump solutions would still remain more expensive heating solution than fossil natural gas, because of the expensive power network tariffs and heavy power taxation.

An alternative worth to investigate would be to direct the tax incomes from the heating related $\mathrm{CO}_{2}$-tax directly to reduce components in the heat pump power tariff, like levies and energy taxes like the EEG-surcharge. Since only a fraction of power is needed for the heat pump heating compared to natural gas boilers, i.e. the ratio between the seasonal COP and the boiler efficiency, a multiple effect of the directed $\mathrm{CO}_{2}$-tax resources can be expected. A $\mathrm{CO}_{2}$-tax income of 10 euro/MWh natural gas would provide an equivalent potential of a 35 euro/MWh reduction in the EEG surcharge, if a seasonal COP of 3 and boiler efficiency of 0.85 is assumed. The effect of this tax redirection can be seen in Fig. 9 below.

All hybrid gas/heat pump scenarios would reach clear profitability from the end customers point of view, compared to the NG heating with $\mathrm{CO}_{2}$-tax of 50 euro/tonCO $\mathrm{CO}_{2}$. It is especially worth mentioning, that the A2WHP-NG69 scenario would only be slightly more expensive than NG heating without the $\mathrm{CO}_{2}$-tax, which probably would make such policy socially more acceptable.

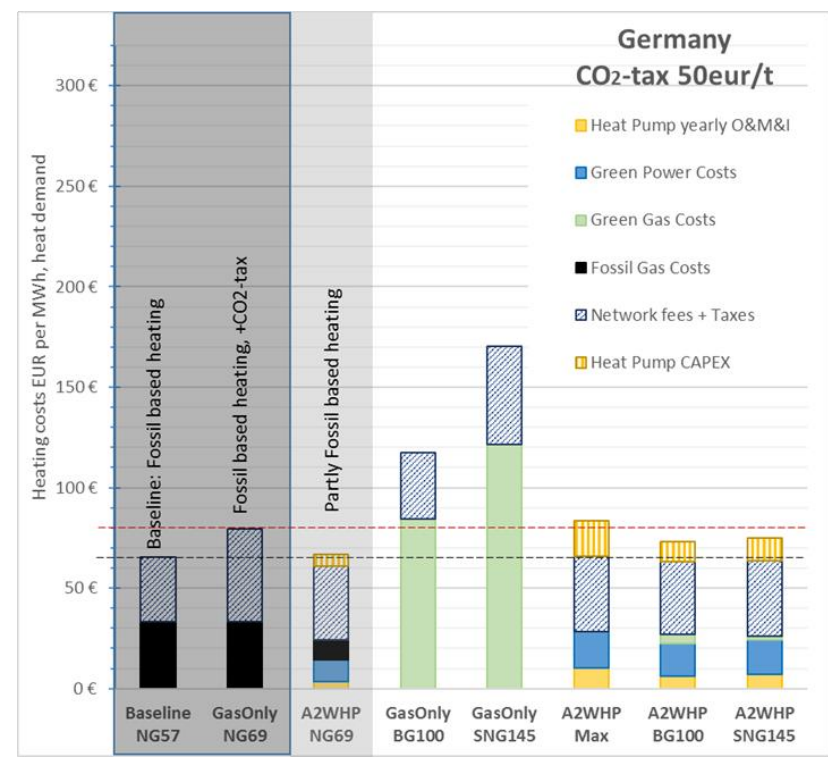

Fig 9 End customer heating costs for the appartment building "2005" with $70 / 40$ radiator system, estimated for a $\mathrm{CO} 2$-tax of 50eur/t, redirected to reduce the EEG-surcharge in heat pump power tariffs of Germany

\section{CONCLUSIONS}

The main conclusions that can be drawn from the results are the following. In Finland it is economically sound for the end-customer to augment or replace natural gas heating by an air-to-water heat pump solution, at the same time significantly reducing emissions. However, today direct gas heating is not so common in Finland, since larger buildings in cities are generally connected to the city's DH grid. In Germany, with a very strong position of gas heating, the high surcharges which are placed on green electricity make the heat pump solution economically unattractive. A relatively low fuel tax would change the situation in favor of the heat pump also in Germany. In both countries reducing emissions of gas-heated 
buildings by substituting fossil natural gas by SNG would significantly increase heating costs.

In future research, it would be necessary to study the effect of increasing penetration of heat pump heating on gas and electricity distribution companies.

\section{REFERENCES}

[1] IRENA, "Renewable Energy in District Heating and Cooling, A sector roadmap for REmap," Int. Renew. Energy Agency, no. March, 2017.

[2] Eurostat, "Energy products used in the residential sector," Statistics Explained, 2019.

[3] Eurostat, "Energy consumption in households by type of end-use," Statistics Explained, 2019. [Online]. Available: https://ec.europa.eu/eurostat/statistics-

explained/index.php/Energy_consumption_in_households\#Energ y_consumption_in_households_by_type_of_end-use.

[4] Federal Ministry for Economic Affairs and Energy, "This is how Germans heat their homes," Energiewende direkt, 2015. .

[5] M. Maivel and J. Kurnitski, "Heating system return temperature effect on heat pump performance," Energy Build., vol. 94, pp. 7179, May 2015.

[6] T. Nowak, "Heat Pumps - Integrating technologies to decarbonise heating and cooling," 2018.

[7] J. Hirvonen, "Peak year for heat pumps. Sales verged on 100,000 pumps. Milestone of one million pumps broken." The Finnish Heat Pump Association (SULPU), 2020.

[8] Statistics Finland, "Maalämmön osuus lämmönlähteenä kasvussa," 2016.

[9] EurObserv'ER, "The State of Renewable Energies in Europe," Ed. 2018 - 18th EurObserv'ER Rep., 2018.

[10] Süddeutsche Zeitung and Heidorn GmbH., "Gaspreise 2020 - jetzt aktuelle Gaspreise vergleichen und günstigen Gas-Preis sichern.” [Online]. Available: https://www.sueddeutsche.de/vergleich/gas/gaspreise/.

[Accessed: 01-Mar-2020].

[11] Several german biogas suppliers, "Biogas offers to residential end customers." [Online]. Available: www.naturstrom.de. [Accessed: 01-Mar-2020].

[12] P. Collet et al., "Techno-economic and Life Cycle Assessment of methane production via biogas upgrading and power to gas technology," Appl. Energy, vol. 192, pp. 282-295, Apr. 2017.

[13] M. Van Dael et al., "Techno-economic assessment of a microbial power-to-gas plant - Case study in Belgium," Appl. Energy, vol. 215, pp. 416-425, Apr. 2018.

[14] ENEA Consulting, "The Potential of Power-To-Gas," vol. 33, no. 0, p. 51, 2016.

[15] sähkövertailu.fi, "No Title." [Online]. Available: https://sahkovertailu.fi/. [Accessed: 01-Mar-2020].

[16] B. der D. H. e. V. (BDH) and B. W. (BWP), "BDH / BWP-Position zur Sektorkopplung und zum Strompreis," 2017.

[17] Bundesverband Wärmepumpe (BWP), "No Title." [Online]. Available: www.waermepumpe.de. [Accessed: 01-Mar-2020].

[18] C. Finland, "No Title." [Online]. Available: https://www.caruna.fi/palvelut/tuotteet-ja-hinnat/sahkonjakelunhinta. [Accessed: 01-Mar-2020].

[19] Nibe Energy Systems, "Nibe F2120 Ilma/vesilämpöpumppu (english Air/water heat pump)," Nibe Energy Systems, 2019.

[20] Mitsubishi Electric, "Hot water heat pump CAHV-P500YA-HPB Data Book," 2019.

[21] Finnish Meteorologial Institute, "No Title." [Online]. Available: www.fmi.fi. [Accessed: 01-Feb-2020].

[22] "Renewables.ninja," 2018. . 